\title{
Pur $\alpha$ Protein Implicated in Dendritic RNA Transport Interacts with Ribosomes in Neuronal Cytoplasm
}

\author{
Yanmei Li, ${ }^{a}$ Katsuya KoIKe, ${ }^{a}$ Sachiyo OHashi, ${ }^{a}$ Tomoko Funakoshi,${ }^{a}$ Masahiro Tadano, ${ }^{a}$ \\ Shunsuke KobayaShI, ${ }^{a}$ Kaijiro ANZaI, ${ }^{*, a}$ Noriyuki ShIBATA, ${ }^{b}$ and Makio KobaYASHI ${ }^{b}$ \\ Department of Biochemistry, College of Pharmacy, Nihon University, ${ }^{a}$ Narashinodai, Funabashi, Chiba 274-8555, Japan \\ and Department of Pathology, Tokyo Women's Medical University, ${ }^{b}$ Kawada-cho, Shinjuku-ku, Tokyo 162-8666, Japan. \\ Received October 19, 2000; accepted November 29, 2000
}

\begin{abstract}
We have previously reported that pur $\alpha$, known to be a regulator of DNA replication and transcription, links neural BC1 RNA to microtubules via dendrite-targeting RNA motifs. Here we demonstrate the subcellular localization of pur proteins within the brain. Pur proteins were detected in neurons but not in glia. Immunohistochemical staining was prominent in perikarya and proximal dendrites and also extended into primary dendritic processes, but no significant signals were detected in the distal regions of dendrite. When homogenates of mouse brain were fractionated, pur $\alpha$ was most concentrated in the microsomal pellet. Consistently, pur $\alpha$ co-fractionated with free polysomes as well as with membrane-bound polysomes and the association with polysomes was mediated by binding ribosomal subunits. Levels of ribosomes with pur $\alpha$ progressively increased during postnatal development of the brain.
\end{abstract}

Key words pur $\alpha$; ribosome; dendritic RNA; translation; RNA transport

We have previously shown that the single stranded DNAand RNA-binding proteins, pur $\alpha$ and its isoform pur $\beta,{ }^{1,2)}$ which are implicated in the control of DNA replication and transcription, ${ }^{3-8)}$ link neural $\mathrm{BC} 1$ RNA to microtubules (MTs). ${ }^{9)}$ The pur-binding site is within the $5^{\prime}$-proximal region of $\mathrm{BC} 1 \mathrm{RNA}$ which contains putative dendrite-targeting RNA motifs, $\left.{ }^{9}, 10\right)$ suggesting that in the cytoplasm of neurons these nuclear proteins are involved in the process of $\mathrm{BC} 1$ RNA transport along dendritic MTs. The expression of pur proteins is developmentally regulated, ${ }^{8)}$ and mimics the time course of $\mathrm{BC} 1$ RNA expression in the postnatal brain. ${ }^{11)}$ Moreover, we recently observed that pur proteins were required for $\mathrm{BC} 1 \mathrm{RNA}$ expression in vitro as a transcriptional activator. ${ }^{12)}$ Therefore, it is suggested that these proteins have dual roles in the neuronal nucleus and cytoplasm in the establishment and the maintenance of uneven distribution of BC1 RNA within developing neurons as well as within mature, polarized neurons in the adult brain. Nevertheless, it seems unlikely that $\mathrm{BC} 1 \mathrm{RNA}$ is the sole target of these proteins, as the nucleotide sequences bound by pur proteins, which contain GGN repeats, ${ }^{1,2)}$ are relatively simple and have been found in several RNAs. ${ }^{2,9,10,13,14)}$ These observations suggest that pur proteins may also link other dendritic RNAs including rRNA to MTs. Therefore, it is necessary to define the target RNA that is specifically bound by these proteins in vivo, particularly in neuronal cytoplasm, and to analyze the subcellular localization of the pur proteins.

\section{MATERIALS AND METHODS}

Preparation of Antibodies Pur $\alpha$-specific multiple antigenic peptide (MAP) (amino acids $291-313)^{13}$ was synthesized according to the method of Tam. ${ }^{15)}$ Peptide-specific polyclonal antibodies were produced in rabbits and purified using peptide-coupled aminoalkyl agarose. An antibody against full-length pur $\alpha$ was also raised in rabbits using a glutathione- $S$-transferase (GST)-pur $\alpha$ fusion protein as an immunogen, and affinity-purified with histidine-tagged pur $\alpha$ protein-coupled aminoalkyl agarose (Bio-Rad). An antibody against full-length Translin protein was produced in rabbits using a GST-Translin fusion protein, and affinity-purified before use. Anti Bip protein was purchased from Affinity Bioreagents, Inc.

Immunohistochemistry Dissected whole animal brains fixed with $20 \%$ formalin were embedded in paraffin. Then, multiple $6 \mu \mathrm{m}$-thick deparaffinized sections were pretreated with 3\% hydrogen peroxide for blocking endogenous peroxidase activity and with normal goat IgG for blocking non-specific binding of the primary antibody, and then incubated overnight at $4{ }^{\circ} \mathrm{C}$ with the antibody against full-length pur $\alpha$ (diluted $1: 100$ ). Immunoreaction products were visualized with the avidin-biotin immunoperoxidase complex (ABC) method using the $\mathrm{ABC}$ kit (Vector Laboratories) and 3,3' -diaminobenzidine tetrahydrochloride as the chromogen. ${ }^{16)} \mathrm{Im}$ munostained sections were counterstained with methyl green. The specificity of the antibody was confirmed by preincubation of the antibody with $1.9 \mathrm{mg}$ GST-pur $\alpha$ fusion protein $/ \mathrm{ml}$ at $4{ }^{\circ} \mathrm{C}$ overnight.

Subcellular Fractionation Subcellular fractionation was conducted essentially according to the method of Feng et $a l .{ }^{17)}$ and all subsequent procedures were performed at $4{ }^{\circ} \mathrm{C}$, unless otherwise stated. Mouse brains were homogenized in a buffer $[0.25 \mathrm{~m}$ sucrose, $50 \mathrm{~mm}$ Tris- $\mathrm{HCl}, \mathrm{pH} 7.4,5 \mathrm{~mm}$ $\mathrm{MgCl}_{2}, 25 \mathrm{~mm} \mathrm{KCl}, 1 \mathrm{~mm}$ phenyl methyl sulfonyl fluoride (PMSF)] and centrifuged at $1000 \boldsymbol{g}$ for $10 \mathrm{~min}$, giving a pellet (crude nuclei). The supernatant was centrifuged again at $10000 \mathrm{~g}$ for $30 \mathrm{~min}$, giving a mitochondria pellet $(\mathrm{Mt})$ and post-mitochondria supernatant (PMS). The PMS was centrifuged at $100000 \boldsymbol{g}$ for $1 \mathrm{~h}$, giving a pellet (P100) and the soluble cytoplasm (S100) fraction. The crude nuclei were resuspended in $1.6 \mathrm{M}$ sucrose and centrifuged through $2.1 \mathrm{M}$ sucrose at $150000 \boldsymbol{g}$ for $1 \mathrm{~h}$, giving purified nuclei $(\mathrm{Nu})$. For more detailed fractionation, the PMS was layered over $1.3 \mathrm{M}$ sucrose and centrifuged at $225000 \mathrm{~g}$ for $1 \mathrm{~h}$. The resulting $0.25 \mathrm{M}$ sucrose top layer (soluble cytoplasm layer), $0.25 / 1.3 \mathrm{M}$ interface containing smooth endoplasmic reticulum (sER) 
and the pellet containing rough endoplasmic reticulum (rER) and free polysomes were collected. PMS was also centrifuged at $225000 \boldsymbol{g}$ for $2 \mathrm{~h}$ on a discontinuous sucrose gradient consisting of $0.25,1.35,1.6,2.0 \mathrm{M}$ sucrose to separate rER from free polysomes. ${ }^{17)}$ After centrifugation, the top layer, $0.25 / 1.35 \mathrm{M}$ interface, $1.6 / 2 \mathrm{M}$ interface and pellet fractions were collected, containing soluble cytoplasmic protein, sER, rER and free polysomes, respectively. Proteins of each fraction were analyzed by sodium dodecyl sulfate-polyacrylamide gel electrophoresis (SDS-PAGE), followed by Western blot analysis using the required pur peptide-specific antibodies.

Polysome Analysis Mouse brains were homogenized as described above in the presence of $100 \mu \mathrm{g}$ cycloheximide $/ \mathrm{ml}$ and centrifuged at $10000 \boldsymbol{g}$ for $30 \mathrm{~min}$ to obtain PMS. After treatment with $0.5 \%$ Nonidet P-40 (NP40) in the presence or absence of $25 \mathrm{~mm}$ ethylene diamine- $N, N, N^{\prime}, N^{\prime}$-tetra acetic acid (EDTA) for $30 \mathrm{~min}$, the PMS was centrifuged on a linear sucrose gradient $(8.5-45 \%$ made with $20 \mathrm{~mm}$ Tris- $\mathrm{HCl}, \mathrm{pH}$ 7.4, $2 \mathrm{~mm} \mathrm{MgCl}_{2}, 50 \mathrm{~mm} \mathrm{KCl}$ ) for $2 \mathrm{~h}$ at $160000 \boldsymbol{g}$. After centrifugation, the gradient was divided into fractions, followed by Western blot analysis. To determine the banding pattern of polysomes, RNA was purified from each fraction and analyzed by agarose gel electrophoresis.

Analysis of Ribosome Subunits on a Sucrose Gradient Mouse brain PMS, treated with $0.5 \%$ NP40, was centrifuged over $5 \mathrm{ml}$ of $30 \%$ sucrose (in $20 \mathrm{~mm}$ Tris- $\mathrm{HCl}$, pH 7.4, $2 \mathrm{~mm}$ $\mathrm{MgCl}_{2}, 50 \mathrm{~mm} \mathrm{KCl}$ ) at $160000 \mathrm{~g}$ for $2.5 \mathrm{~h}$. The resulting polysome pellet was resuspended in the homogenization buffer and centrifuged at $15000 \mathrm{rpm}$ for $10 \mathrm{~min}$ to remove insoluble material. This supernatant was treated with $25 \mathrm{~mm}$ EDTA to dissociate ribosome subunits, and then centrifuged on a 8.5 to $45 \%$ sucrose gradient (in $20 \mathrm{~mm}$ Tris- $\mathrm{HCl}, \mathrm{pH}$ 7.4, $2 \mathrm{~mm} \mathrm{MgCl}_{2}, 50 \mathrm{~mm} \mathrm{KCl}$ and $25 \mathrm{~mm}$ EDTA) at $160000 \boldsymbol{g}$ for $9.5 \mathrm{~h}$.

\section{RESULTS AND DISCUSSION}

We have suggested that pur proteins are involved in the process of BC1 RNA transport along dendritic microtubules (MTs). ${ }^{9}$ However, we have not yet defined the localization of these proteins within the brain. Thus, here we have investigated whether pur proteins are actually present in the neuronal somatodendritic compartment using an antibody against full-length pur $\alpha$ (Fig. 1a, inset). In accordance with our previous observations, pur proteins were detected in neurons, but not in glia throughout the rat brain sections processed for immunohistochemistry. Figure 1a shows the cerebellar region of rat brain. Staining was very dense in perikarya and proximal dendrites of Purkinje cells, and also extended from the cell body into primary dendritic processes (Fig. 1b). Lower levels of staining were also detected in granule cells and other neuronal cells (Figs. 1a, b). Pur staining was lost by pre-incubation of the antibody with GST-pur $\alpha$ (Fig. 1c) or histidine-tagged pur proteins (data not shown), while the signal was not absorbed with GST protein alone (data not shown), indicating that the staining is specific. Thus, pur proteins were detected in the neuronal dendrites. However, unlike Translin, which distributes throughout the dendritic arbors, ${ }^{18,19)}$ no significant staining was observed in the distal regions of dendrite. The difference in the extent of
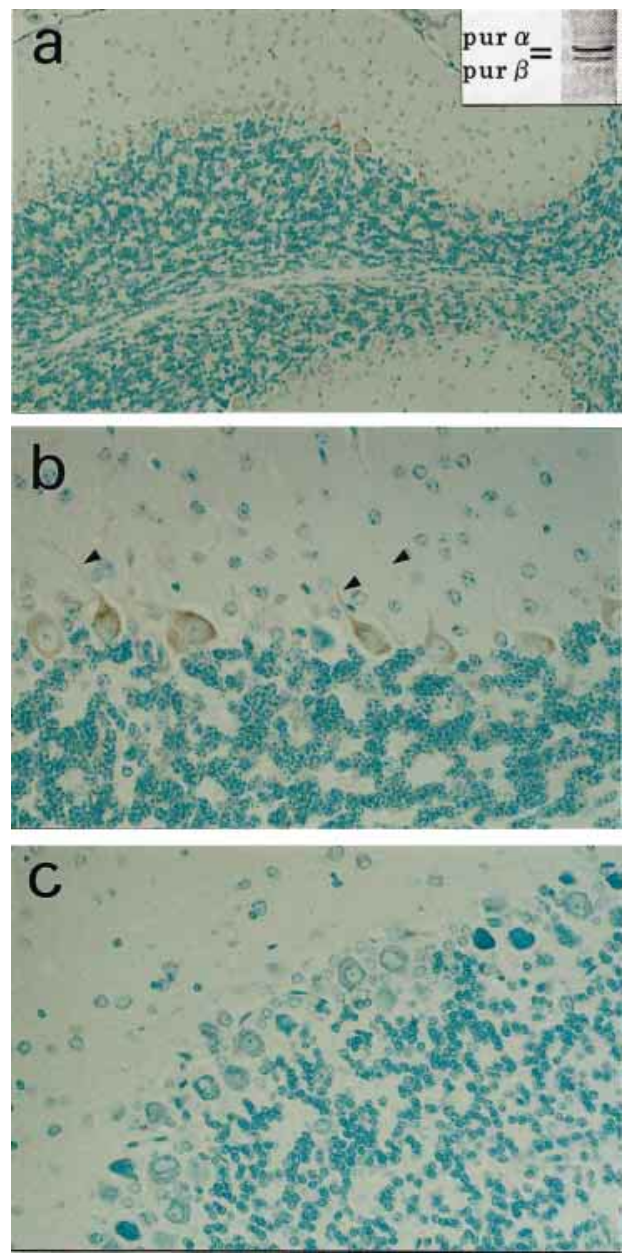

Fig. 1. Somatodendritic Localization of Pur Proteins in Neurons

(a) Pur proteins detected in Purkinje cells in the rat cerebellum using an anti fulllength pur $\alpha$ IgG. Inset: specificity of the antibody used. Pur $\alpha$ (upper band) was detected in brain extracts by Western blot analysis. Small amount of pur $\beta$ (lower band) was also detected due to the sequence similarity between the two isoforms. ${ }^{13)}$ (b) Higher magnification view of the center of panel a. Arrowheads: pur protein-positive primary dendritic processes of Purkinje cells. (c) Staining is completely absorbed with GST-pur $\alpha$ fusion proteins.

dendritic distribution of pur $\alpha$ and Translin proteins suggests that there are some different transport mechanisms in neurons. Mayford et al. ${ }^{20)}$ reported that CaMKII $\alpha$ mRNA was found in the most distal regions of dendrite and its subcellular distribution differs from that of MAP2 mRNA which is found only in the proximal region of dendrite. Pur $\alpha$ proteins may play a role in the process of RNA transport to the proximal portion of dendrite.

Next we analyzed the subcellular distribution of pur $\alpha$ proteins. Mouse brain homogenate was initially fractionated by sequential velocity centrifugation, resulting in fractions designated as nuclei $(\mathrm{Nu})$, mitochondria $(\mathrm{Mt})$, microsomal pellet (P100) and soluble cytoplasm (S100). The same amount of total protein from each fraction was examined for the presence of pur proteins by Western blot analysis. Fig. 2a shows that pur $\alpha$ was most concentrated in P100 together with Bip protein, a marker protein for $\mathrm{rER},{ }^{21)}$ while Translin protein ${ }^{22}$ was almost exclusively detected in the soluble cytoplasmic fraction (also see ref. 23). The percentage of total pur $\alpha$ in the P100 fraction was also calculated by densitometric quantification of the Western blot: Level of pur $\alpha$ in P100 was $14 \%$. Despite this relatively low level, the higher concentra- 

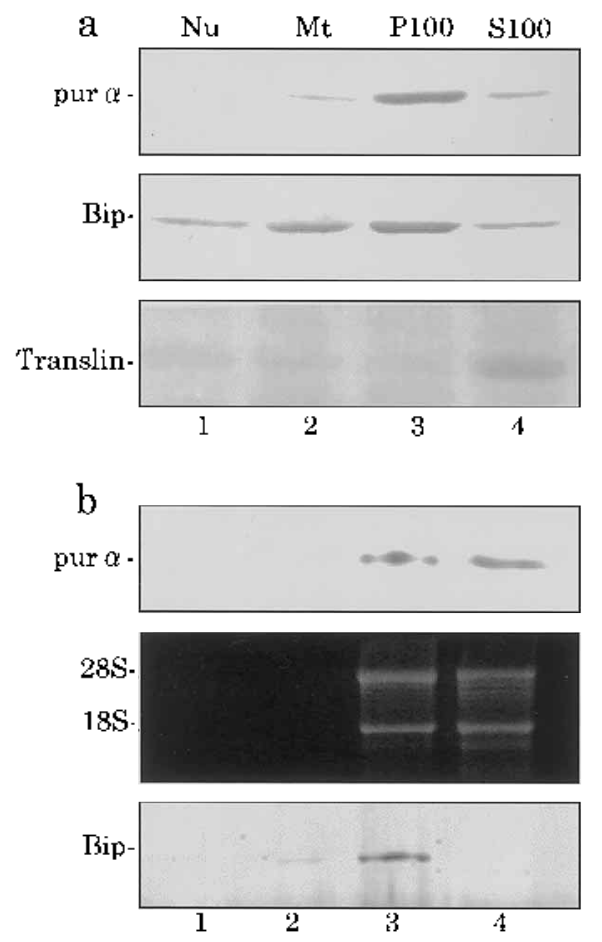

Fig. 2. Subcellular Distribution of Pur $\alpha$ within the Mouse Brain

Twenty five micrograms protein of each subcellular fraction was analyzed by Western blotting. Antibodies used are indicated at the left. (a) Subcelluar fractions: 1, nuclei (Nu); 2, mitochondria (Mt); 3, microsomal pellet (P100); 4, soluble cytoplasm (S100). (b) Discontinuous sucrose gradient fractions: $1,0.25 \mathrm{M}$ sucrose layer (soluble cytoplasm); 2, 0.25/1.25 M sucrose interface (sER); $3,1.6 / 2 \mathrm{M}$ sucrose interface (rER); 4, pellet (free polysome). Ribosomes were detected in fractions 3 and 4 (bottom panel). The positions of $28 \mathrm{~S}$ and $18 \mathrm{~S}$ rRNAs are indicated.

tion of pur $\alpha$ in this fraction is important, as the P100 fraction reportedly contains mainly rER and free polysomes. Thus, since pur $\alpha$ proteins bind RNA, these proteins may be involved in the control of protein synthesis in neuronal cells. To determine whether the pur protein co-fractionates with RNA-containing structures, PMS was centrifuged through a discontinuous sucrose gradient. Pur $\alpha$ was mainly concentrated in the pellet together with the ribosomes (data not shown; but see Fig. 2b), which suggests that pur $\alpha$ associates with the polysomes via rRNA and/or mRNA. In support of this, RNase A treatment of PMS before centrifugation decreased pur protein recovery from the pellet, with a concomitant increase in the recovery from the soluble cytoplasm layer of the gradient $(0.25 \mathrm{~m}$ sucrose layer; data not shown but see Fig. 3d). A more detailed fractionation experiment was also performed, and revealed that pur $\alpha$ co-fractionated with rER (1.6/2.0 M sucrose interface) as well as with free polysomes (pellet) (Fig. 2b). It is notable that rRNA was found in both rER and pellet, but Bip protein appeared confined to the $1.6 / 2.0 \mathrm{M}$ interface, indicating that the $1.6 / 2.0 \mathrm{M}$ interface and the pellet correspond to the rER and the free polysome, respectively.

In order to obtain direct evidence of the association of pur proteins with polysomes, we analyzed pur protein cosedimentation with polysomes on a sucrose gradient. Figure $3 \mathrm{a}$ shows that pur $\alpha$ was detected throughout the gradient, whose banding profile was almost identical with that of ribosomes and polysomes (Fig. 3e). When PMS was treated with EDTA before centrifugation, pur $\alpha$ shifted completely to the lower sucrose fractions (Fig. 3f) together with the dissociated

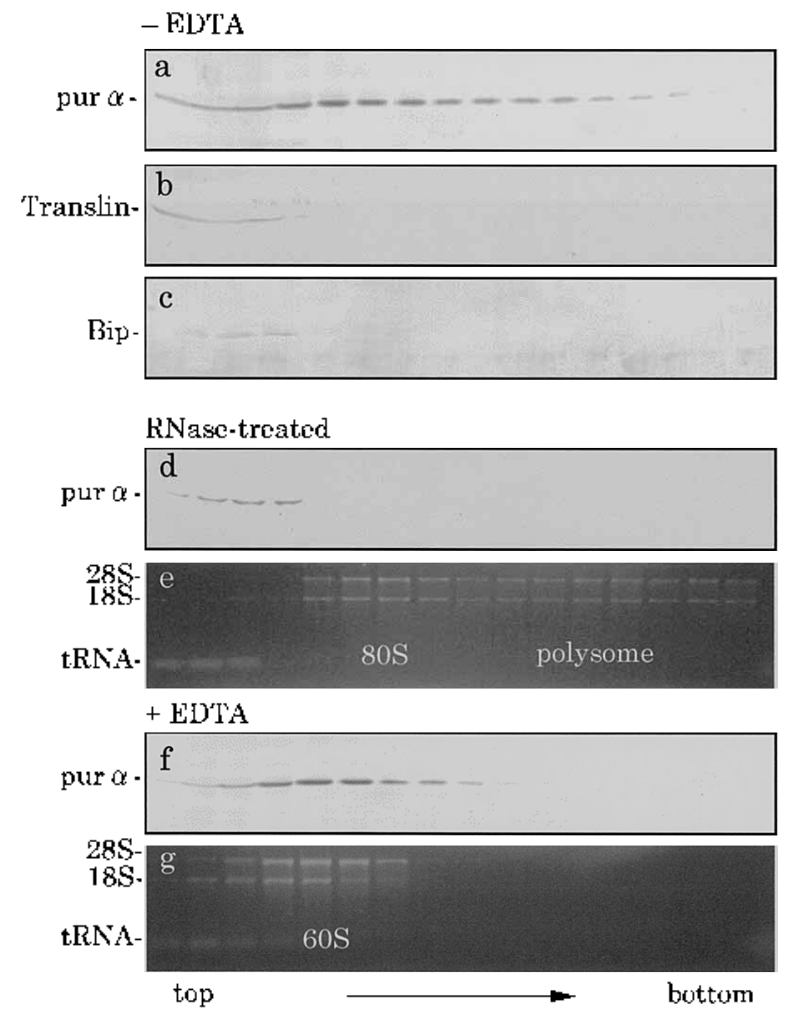

Fig. 3. Sucrose Gradient Profile of Polysomes Bearing Pur Proteins

Post mitochondria supernatant fraction of brain homogenate treated with (f, g) or without $(\mathrm{a}-\mathrm{e})$ EDTA was centrifuged on a sucrose gradient, and fractionated. Samples shown in d were treated with $100 \mu \mathrm{g}$ RNase $\mathrm{A} / \mathrm{ml}$ at $4{ }^{\circ} \mathrm{C}$ before centrifugation. An aliquot of each fraction was subjected to Western blot analysis. Antibodies used are indicated at the left. Panels e and g show the centrifugation profile of ribosomes. Centrifugation was from left to right. The positions of $60 \mathrm{~S}, 80 \mathrm{~S}$ ribosomal particles and polysome are indicated.

ribosomal subunits (Fig. 3g). Note that the distribution profile of pur $\alpha$ was similar to that of the 60S ribosomal subunit. RNase treatment of PMS also shifted all pur proteins to the top fractions (Fig. 3d). This shift appeared to be due to the degradation of rRNA, as no intact rRNAs were recovered from the gradient after RNase treatment (data not shown). Taking the above results together, it is suggested that pur $\alpha$ proteins associated with the polysomes through binding the ribosomal subunits. As a control, we observed that Translin protein (Fig. 3b), another class of RNA-binding protein which is reportedly interactive with BC1 RNA (23), and Bip protein (Fig. 3c) did not associate with polysomes. In accordance with our previous observations, BC1 RNA was shown to co-sediment with the Translin protein by Northern blot analysis (data not shown, but see ref. 23), suggesting the association of pur $\alpha$ with polysomes is specific.

Next we investigated whether pur $\alpha$ interacts with ribosomal subunits. Purified brain polysomes from neonatal or adult mice were dissociated into subunits with EDTA and then centrifuged through a continuous sucrose gradient. It has been reported that polysomes are dissociated into ribosomal subunits and mRNA-protein complexes in the presence of EDTA. ${ }^{24)}$ As shown in Fig. 4, pur $\alpha$ predominantly bound to the $60 \mathrm{~S}$ subunit. Co-sedimentation of pur proteins with ribosomes is indicative, but does not provide proof for the stable interaction of pur $\alpha$ with ribosomes. So we examined next whether the binding capacity is resistant to $\mathrm{KCl}$ treatment. For this, we analyzed P100 fractions pretreated with 

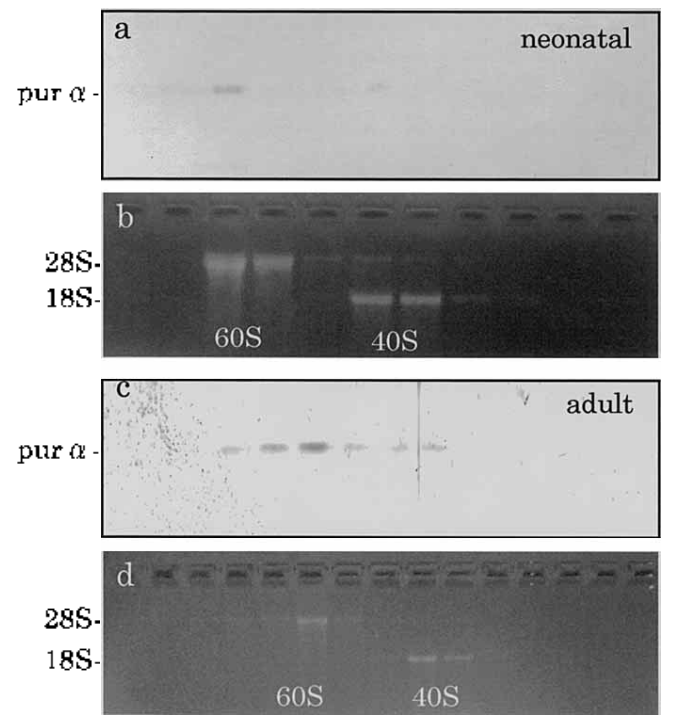

Fig. 4. Sucrose Gradient Profiles of Ribosomal Subunits Containing Pur $\alpha$ Purified polysomes were treated with EDTA, and centrifuged on a sucrose gradient. Distribution of pur $\alpha(\mathrm{a}, \mathrm{c})$ was determined by Western blotting. Postnatal day of mice used: day $7(\mathrm{a}, \mathrm{b})$ and day $28(\mathrm{c}, \mathrm{d})$. Centrifugation profiles of ribosomal subunits are shown in panels $\mathrm{b}$ and $\mathrm{d}$. The positions of $40 \mathrm{~S}$ and $60 \mathrm{~S}$ ribosomal particles are indicated.

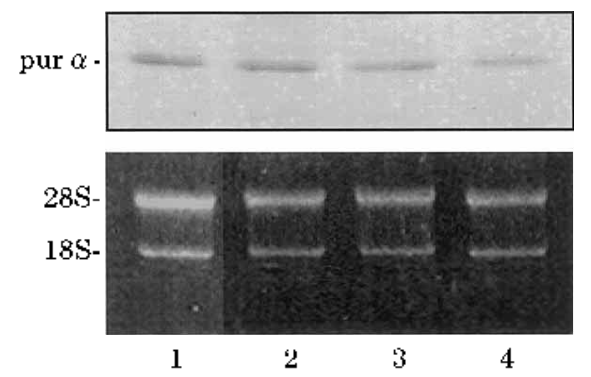

Fig. 5. Stability of the Binding of Pur $\alpha$ to Ribosomes

$\mathrm{P} 100$ fractions were treated with $0.5 \%$ deoxycholate and varying doses of $\mathrm{KCl}$. The samples were then centrifuged and the resulting ribosome pellets were analyzed by Western blotting. $\mathrm{KCl}$ concentrations: $80 \mathrm{mM}$ (1); $150 \mathrm{mM}$ (2); $500 \mathrm{mM}$ (3); $1 \mathrm{M}$ (4). Note all samples contained the same amount of ribosomes (lower panel).

varying doses of $\mathrm{KCl}$. As shown in Fig. 5, a significant amount of pur $\alpha$ remained associated with ribosomes even after treatment with $1 \mathrm{M} \mathrm{KCl}$, demonstrating the tight association of pur $\alpha$ with ribosomes. However, this does not necessarily mean that the pur $\alpha$ is a ribosomal protein which is ubiquitously expressed in all tissues. In fact, very low levels of pur $\alpha$ are associated with ribosomes from the liver (Fig. $6)$. Therefore, it is possible that pur $\alpha$ may modulate the ribosome activities such as peptide bond formation to control protein synthesis in the somatodendritic compartment of neurons. Next we examined whether concentrations of pur $\alpha$ in the P100 fraction were developmentally regulated. Figure $7 \mathrm{a}$ shows that the concentration was very low in neonatal mice but it was elevated progressively to the adult level as development proceeded. These results appear to be caused by an increase in ribosomes bound by pur $\alpha$ proteins since similar developmetal expression was observed when the same amount of ribosomes were analyzed for each time point in a separate series of experiment (Fig. 7b). Taken together, there is an interesting possibility that pur $\alpha$ may also be involved in the control of mRNA translation by binding ribosomes

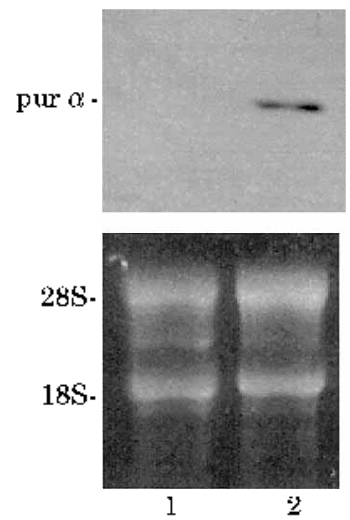

Fig. 6. Pur $\alpha$ Proteins in Liver Ribosomes

The same amount of purified polysomes ( $20 \mu \mathrm{g}$ RNA) from the liver (1) and brain (2) were analyzed by Western blotting. Bottom panel: ribosomal RNA.
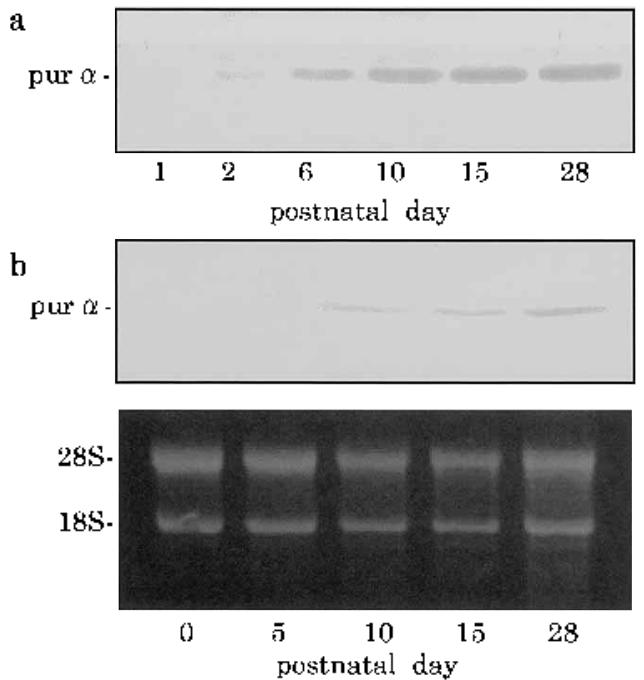

Fig. 7. Developmental Change in Pur $\alpha$ Expression

(a) The same amount of proteins $(20 \mu \mathrm{g})$ from P100 fraction were analyzed by Western blotting. (b) The same amount of ribosomes (10 $\mu \mathrm{g}$ RNA) in P100 fraction (lower panel) were analyzed in a separate experiment by Western blotting (upper panel). Postnatal day of mice and the positions of rRNAs are indicated.

during postnatal development of the brain.

Recently, we observed that an association of the pur proteins with MTs was lost by RNase A treatment, suggesting that the pur proteins interacted with MTs in the form of RNP. These RNPs may be ribosomes, as an immunoprecipitation study showed that $\mathrm{NaCl}$ extracts of MTs also contained ribosomes which were associated with pur proteins (unpublished observations). These observations can be taken as an indication that the pur proteins may attach ribosomes or polysomes to MTs. In this respect, it is intriguing to examine whether pur proteins are present in granules containing poly $(\mathrm{A})^{+}$ mRNAs, translational factors and ribosomes. ${ }^{25}$ ) Another trans-acting protein involved in mRNA transport in neurons, mammalian Staufen, co-localizes with such fluorescent dye SYTO-positive granules and moves along dendritic MTs in hippocampal neurons. ${ }^{21,26,27)}$ Pur proteins have been known as the multifunctional nuclear proteins that play regulatory roles in both transcription and replication. ${ }^{3-8)}$ Recently, we also observed that pur $\alpha$ was essential for BC1 RNA expression in vitro as a transcriptional activator. ${ }^{12)}$ Furthermore, the protein bound to nascent $\mathrm{BC} 1 \mathrm{RNA}$ to form an RNP in the 
transcription reaction mixture containing brain nuclear extracts, suggesting a possible role in RNA export from the nucleus. In this context, our present findings suggest that the pur proteins can play multiple roles in the different cell compartments, although it remains to be determined whether these proteins actually affect ribosome functions in neurons. Kelm et $a{ }^{28)}$ recently reported that a pur $\alpha /$ pur $\beta /$ MSY1 complex, which represses transcription of the $\alpha$-actin gene, may impair translation of $\alpha$-actin mRNA through specific protein-mRNA interactions. It has also been reported that several other nuclear proteins such as heterogeneous nuclear RNP complex protein (hn RNP) $\mathrm{A} 2^{29)}$ or hn RNP K and hn RNP E1 ${ }^{30)}$ enhance or silence protein synthesis, respectively. Therefore, there is an interesting possibility that pur $\alpha$ proteins may integrate diverse processes of gene expression from transcription to mRNA translation operated in the neuronal nucleus and cytoplasm.

Acknowledgements We wish to thank Mr. Mizuho Karita and Mr. Fumiaki Muramatsu for their excellent technical assistance in immunohistochemistry. This work was supported in part by a Grant-in-Aid from the Ministry of Education, Science and Culture of Japan.

\section{REFERENCES}

1) Bergemann A. D., Johnson E. M., Mol. Cell Biol., 12, 1257-1265 (1992).

2) Gallia G. L., Darbinian N., Tretiakova A., Ansari S. A., Rappaport J., Brady J., Wortman M. J., Johnson E. M., Khalili K., Proc. Natl. Acad. Sci. U.S.A., 96, 11572-11577 (1999).

3) Haas S., Thatikunta P., Steplewski A., Johnson E. M., Khalili K., Amini S., J. Cell Biol., 130, 1171-1179 (1995).

4) Chang C. F., Gallia G. L., Muralidhara V., Chen N. N., Zoltick P., Johnson E. M., Khalili K., J. Virol., 70, 4150-4156 (1996).

5) Jurk M., Weissinger F., Lottspeich F., Schwarz U., Winnacker E. L., Nucleic Acids Res., 24, 2799-2806 (1996).

6) Du Q., Tomkinson A. E., Gardner P. D., J. Biol. Chem., 272, 1499014995 (1997).

7) Kelm R. J., Jr., Elder P. K., Strauch A. R., Getz, M. J., J. Biol. Chem.,
272, 26727-26733 (1997).

8) Tretiakova A., Steplewski A., Johnson E. M., Khalili K., Amini S., J. Cell. Physiol., 181, 160-168 (1999).

9) Ohashi S., Kobayashi S., Omori A., Ohara S., Omae A., Muramatsu T., Li Y., Anzai K., J. Neurochem., 75, 1781-1790 (2000).

10) Muslimov I. A., Santi E., Homel P., Perini S., Higgins D., Tiedge H., J. Neurosci., 17, 4722-4733 (1997).

11) Anzai K.,Goto S., Mech. Ageing Dev., 39, 129-35 (1987).

12) Kobayashi S., Agui K., Kamo S., Li Y., Anzai K., Biochem. Biophys. Res. Commun., 277, 341-347 (2000).

13) Kelm R. J., Jr., Cogan J. G., Elder P. K., Strauch A. R., Getz M. J., J. Biol. Chem., 274, 14238-14245 (1999).

14) Tretiakova A.,Gallia G. L., Shcherbik N., Jameson B., Johnson E. M., Amini S., Khalili K., J. Biol. Chem., 273, 22241-22247 (1998).

15) Tam J. P., Proc. Natl. Acad. Sci. U.S.A., 85, 5409-5413 (1988).

16) Maruoka Y., Kobayashi M., Ogiuchi H., J. Tokyo Wom. Med. Coll., 66, $1120-1128$ (1996).

17) Feng Y., Gutekunst C. A., Eberhart D. E., Yi H., Warren S. T., Hersch S. M., J. Neurosci., 17, 1539-1547 (1997).

18) Kobayashi S., Takashima A., Anzai K., Biochem. Biophys. Res. Commun., 253, 448-453 (1998).

19) Finkenstadt P. M., Kang W.-S., Jeon M., Taira E., Tang W., Baraban J. M., J. Neurochem., 75, 1754-1762 (2000).

20) Mayford M., Baranes D., Podsypanina K., Kandel E. R., Proc. Natl. Acad. Sci. U.S.A., 93, 13250-13255 (1996).

21) Marion R. M., Fortes P., Beloso A., Dotti C., Ortin J., Mol. Cell Biol., 19, 2212-2219 (1999).

22) Aoki K., Suzuki K., Sugano T., Tasaka T., Nakahara K., Kuge O., Omori A., Kasai M., Nature Genet., 10, 167-174 (1995).

23) Muramatsu T., Ohame A., Anzai K., Biochem. Biophys. Res. Commun., 247, 7-11 (1998).

24) Siomi M. C., Zhang Y., Siomi H., Dreyfuss G., Mol. Cell Biol., 16, 3825 -3832 (1996).

25) Knowels R. B., Kosik K. S., Proc. Natl. Acad. Sci. U.S.A., 94, 14804 14808 (1997).

26) Kohrmann M., Luo M., Kaether C., DesGroseillers L., Dotti C. G., Kiebler M. A., Mol. Biol. Cell., 10, 2945-2953 (1999).

27) Wickham L., Duchaine T., Luo M., Nabi I. R., DesGroseillers L., Mol. Cell Biol., 19, 2220-2230 (1999).

28) Kelm R. J., Jr., Elder P. K., Getz M. J., J. Biol. Chem., 27, $38268-$ 38275 (1999).

29) Kwon S., Barbarese E., Carson J. H., J. Cell Biol., 147, 247-256 (1999).

30) Ostareck D. H., Ostareck-Lederer A., Wilm M., Thiele B. J., Mann M., Hentz M. W., Cell, 89, 597-606 (1997). 